\title{
Social Core Value System Leading the Graduate Students' Moral Education
}

\author{
Yu Guo \\ Graduate School, Tianjin University of Finance and Economics, Tianjin, China
}

\begin{abstract}
The moral education is the ideological basis and important content for the graduate students. The moral education of graduate students is significant led by social core value system. We must consider the characteristics and development trend of the graduate students in order to do a good job on their moral education in the new period. We should analyze the present situation and main problems; explore actively the content and method of the graduate students' moral education. Then we can open up a new prospect for the graduate students' moral education.
\end{abstract}

Keywords—-social core value system, graduate students, moral education

\section{以社会主义核心价值体系引领研究生德育教育}

\author{
郭昱 \\ 天津财经大学研究生院, 天津, 中国
}

摘 要 研究生德育教育是研究生教育的思想基础和重要内容, 以社会主义核心价值体系引领研究生德育教育具有重要意义。新 时期做好研究生德育工作必须紧密结合研究生的特点和研究生教育的发展趋势, 分析研究生德育教育的现状和存在的主要问题, 积极 探索研究生德育教育的内容和方法, 不断开创我国研究生德育教育的新局面。

关键词 社会主义核心价值体系，研究生，德育教育

\section{1. 引言}

研究生教育是高等教育人才培养的最高层次, 而研究 生德育教育是研究生教育的重要组成部分, 在研究生的全 面人才培养中具有不可替代的作用。[1]高校研究生德育教 育就是对研究生进行思想、政治、道德、心理健康等方面 的教育, 培养研究生树立正确的世界观、人生观和价值观, 它是将研究生培养成具备较高综合素质的拔尖创新人才的 思想基础和政治保证。

“坚持德育为先, 立德树人, 把社会主义核心价值体 系融入国民教育全过程” 是《国家中长期教育改革和发展 规划纲要（2010-2020 年) 提出的一项重要任务。随着市 场经济体制改革的不断深化, 用社会主义核心价值体系这 一思想指导高校研究生德育工作的实践, 具有重要意义。

2. 以社会主义核心价值体系引领研究生德育教育的 必要性

当今社会是一个大发展、大变革的时代。国际上, 经
济全球化继续深入, 各国交往日益密切, 各种西方文化思 想不断涌入; 国内看, 经济体制深刻变革, 对外开放不断 深入, 思想观念日益变化。尽管研究生思想政治状况的主 流是好的, 但基于研究生在年龄、人生阅历、社会背景等 方面的特征，在国内外各种思潮的影响和冲击下，一些研 究生在思想观念、价值判断上产生了困惑, 表现为理想信 念淡化、社会责任感弱化、片面追逐物质利益等问题, 研 究生群体的价值取向更易多元化。在这种情况下, 如何加 强和完善研究生的德育教育, 提高研究生价值观的整合能 力, 是研究生教育面临的一项重要内容。结合研究生群体 的特征, 以社会主义核心价值体系引领研究生德育教育, 十分必要。

\section{1 是当今时代发展的需要 [5]。}

在党的十六大、十七大报告相关内容的基础上, 党的 十八大报告再次强调要 “紧紧围绕建设社会主义核心价值 体系深化文化体制改革”。研究生德育教育是 “国民教育和 
精神文明建设” 的重要环节, 以社会主义核心价值体系引 领研究生德育教育是社会主义核心价值体系构建与研究生 德育教育发展相结合的必然要求。

\section{2 是构建和谐校园文化的需要。}

大学校园文化是我国社会主义先进文化的重要组成部 分, 对构建我国社会主义核心价值体系具有重要作用。当 前, 西方意识形态、文化思想不断渗透的压力和国内改革 带来的影响侵蚀着大学生的价值观, 使高校校园文化建设 在面对新的历史发展机遇的同时, 也面临着挑战。以社会 共同遵循的社会主义核心价值体系为指导, 在高校中最大 限度地形成共识, 构建和谐校园文化, 对推动高校可持续 发展、培养高素质创新人才、实现建设高水平大学的目标 十分必要。

\section{3 是培养拔尖创新人才的需要。}

社会主义核心价值体系不仅为高校研究生德育教育指 明了正确方向, 为其创新发展提供了新思路、新视角, 而 且它也为广大研究生明确了价值判断的标准, 有利于研究 生形成正确的世界观、人生观和价值观, 有利于研究生综 合素养的培养和提高。社会主义核心价值体系符合研究生 健康成长和全面发展的基本要求, 是研究生思想政治教育 的本质所在, 是新时期加强和改进研究生德育工作的指导 思想, 是培养拔尖创新人才、培养社会主义事业合格建设 者和可靠接班人的重要举措。

\section{3. 我国高校研究生德育教育的现状分析}

2009 年以来, 我国的研究生招生规模和招生结构均面 临着历史性转型和战略性调整。2011 年, 我国研究生在校 生达到近 164.6 万人。总体来看, 广大研究生的思想主流 是好的, 都能热爱祖国、拥护中国共产党的领导、拥护社 会主义, 勤奋学习、勇于探索、敢于创新, 但与本科生相 比, 研究生呈现出独立性强、个体差异性大、价值取向多 元化等特点, 研究生的思想品德素质参差不齐, 高校的研 究生德育工作也缺乏实效性。新形势下, 正确认识研究生 德育教育的现状和存在的问题, 是提高研究生综合素质、 保证研究生培养质量的重要保证。

\section{1 高校对研究生德育工作的认识需加强}

通常认为能考上研究生就代表其已具备了很高的综合 素质, 在研究生教育中也主要重视培养学生的业务素质、 却忽视对其进行世界观、人生观、价值观等德育素质的继 续培养。高校研究生教育管理者当中专门的德育工作队伍
也较贵乏, 在研究生德育工作方面缺少工作的主动性、科 学性和实效性。在研究生数量逐年增加和研究生结构不断 复杂的新形势下, 高校应从认识上加强研究生德育的重要 性, 努力建设一支专业性强的德育工作队伍, 切实提高研 究生德育培养的质量。

\section{2 导师对研究生的思想品德教育需重视[2]}

导师不仅是研究生学业上的指导者和领路人, 也是研 究生思想品德的直接教育者。高水平、高素质的导师队伍 是研究生培养质量的重要保障。多数导师都能以自己高尚 的道德情操、崇高的理想和信念、坚忍不拔的探索精神, 以及正直的为人处事态度给学生树立良好的榜样。但导师 由于日常教学科研任务较重, 与研究生接触时间有限, 使 导师对研究生的教育主要是专业知识的传授和和科研工作 的指导, 而没有更多的时间关注学生的思想品德教育。导 师在关注研究生科研能力、实践能力提高的同时, 更肩负 着关心研究生思想品质、道德情操、价值取向、健康身心 成长与发展的责任。

\section{3 研究生的德育教育内容需完善}

第一, 研究生党员大都具有较高的政治觉悟和思想理 论水平, 但仍有一些研究生党员受社会各种不良现象的影 响, 存在思想松解、组织观念淡薄、社会责任感不强、功 利性强等问题, 严重影响了研究生党员的先锋模范带头作 用。第二, 研究生个体差异性大, 在处理学业、恋爱、就 业、经济等方面问题时, 常常出现矛盾, 给研究生造成不 同程度的心理压力, 出现复杂多样的心理问题, 阻碍了研 究生的全面健康成长和学业的顺利完成。第三, 近年来, 研究生的就业形势日益严峻, 而研究生的就业期望往往较 高, 用人单位则更看重个人的实践能力和应用能力, 这样 双方不可避免会出现较大的矛盾, 一定程度上加大了研究 生的就业压力。因此, 研究生教育管理者应在思想、学习、 生活、就业各方面对研究生开展研究生德育教育。

\section{4 研究生的德育教育方法需改进}

好的教育方法是研究生德育教育取得成效的重要保 证。一直以来, 研究生的德育教育方法比较单一, 表现为: 重视群体教育, 忽视个体教育, 调查工作不够细致、不够 深入, 尚未真正做到因材施教; 重视思想政治教育, 忽视 心理健康教育, 没能较好实现二者的有机结合; 重视思想 政治理论课的灌输, 忽视将我党的核心思想理论渗透到研 究生的日常学习和生活当中。面对日益复杂的社会环境和 互联网的普及, 研究生德育工作也面临许多新问题, 对研 
究生德育教育的方法也应与时俱进, 通过采取灵活多变的 教育方法, 真正做到因材施教。

\section{4. 以社会主义核心价值体系引领研究生德育教育的 对策}

研究生德育教育是一项系统工程, 将社会主义核心价 值体系融入研究生德育教育, 是高校开展研究生德育工作 的重要指导思想。为此, 我们应该以科学的理论和原则为 基础, 结合研究生德育工作出现的新情况、新问题, 从思 想观念、教育内容、教育方法、队伍建设上进行改革和完 善, 以适应和服务于研究生德育教育发展的形势和要求, 为培养拔尖创新人才服务。

4.1 坚持育人为本、德育为先, 不断提高对研究生德育教 育的认识水平

将社会主义核心价值体系贯穿到研究生德育教育中, 就是要以科学的理论为指导, 坚持育人为本、德育为先, 以提高研究生的世界观、人生观、价值观为目标, 培养全 面发展的研究生, 不断开创研究生德育工作的新局面。为 此, 广大研究生教育管理者和导师应不断提高对研究生德 育教育的认识水平, 将德育教育作为培养高素质研究生创 新人才的重要内容, 帮助研究生正确理解社会主义核心价 值体系的基本内涵, 引导他们确立和践行社会主义核心价 值体系, 努力培养德智体全面发展的社会主义合格建设者 和可靠接班人。

\section{2 加强党建工作, 不断推进研究生德育教育质量的提高}

加强研究生党建工作, 是研究生德育教育的关键环节。 由于一些研究生在本科上学期间或原工作单位就已入党, 使得研究生党员的基数较大, 而且, 在读研期间, 高校的 基层党组织为了吸收更多的高层次优秀人才加入中国共产 党, 一定程度上也加大了研究生党员的发展力度。数量上 的优势并不代表其质量就高, 部分研究生党员仍不同程度 地存在思想松解、政治觉悟不高、组织观念淡薄、功利性 较强等现象, 阻碍了研究生党员的先锋模范带头作用的发 挥。因此, 高校应大力加强研究生党建工作, 在推优、发 展、培养、管理各个环节狠抓研究生党员质量, 以宁缺勿 滥为原则, 做到成熟一个、发展一个, 将研究生党建工作 真正落到实处, 充分体现研究生党员的先锋模范带头作用。

4.3 坚持理论与实践相结合, 不断丰富研究生德育教育的 内容

研究生德育教育要树立创新意识, 将课堂教学与实践
教育相结合, 通过丰富教学内容, 加强研究生对社会主义 核心价值体系的认识, 提高研究生的思想道德素质和人文 心理素质。在课堂教学方面, 高校应充分发挥思想政治理 论课的主导作用, 让社会主义核心价值体系进课堂、进教 材、进研究生头脑, 增加研究生社会主义核心价值体系的 理论认知。在实践教育方面, 高校应不断探求新的思路和 对策, 积极拓展研究生德育教育的内容和关注点, 开展 “研 究生学术论坛”、“研究生学术文化节”、“研究生职业生涯 规划”、“研究生心理咨询服务” 等形式多样、内容丰富的 实践活动, 引导研究生积极参与, 用理论指导实践, 帮助 研究生深刻领会社会主义核心价值体系的意义, 也有助于 研究生明确自身发展目标、培养良好的学术道德、形成健 康的心理。

\section{4 注重融合创新, 积极探索研究生德育教育的新方法}

教育方法的融合创新是研究生德育教育有效进行的方 法保证。单一的教育方法已难以适应研究生德育教育的发 展态势, 日益复杂的研究生德育问题要求采用个体化和综 合化相结合的教育方法, 不断融合创新。一方面, 根据教 育内容和教育对象的差异性, 针对不同的情况确定具体且 有效的教育方法, 并随着事态的变化而随时调整教育方法, 认识到思想教育、政治教育、道德教育、心理教育所运用 教育方法的不同。另一方面, 在个体化教育方法基础上, 重视多种方法的综合化, 采用综合化教育方法, 可以灵活 处理和动态解决研究生德育教育中出现的新问题、新困难。 高校的研究生德育教育要注重 “引导” 和 “疏导”, 以理服 人、以情服人, 帮助研究生正确地将社会主义核心价值体 系转化为自身的信念, 并自觉地运用到自己的行动中。

4.5 加强和谐校园文化建设, 努力营造研究生德育教育的 良好氛围 ${ }^{[4]}$

和谐校园文化建设对树立和弘扬社会主义核心价值体 系具有重要的作用, 也是促进研究生德育工作创新的重要 途径。高校和谐校园文化建设必须紧紧围绕社会主义核心 价值体系, 注重和谐校园文化对研究生德育教育的推动作 用, 努力促进和谐校园文化与德育教育内容、教育方法的 结合, 发挥和谐校园文化的熏陶作用, 为研究生自觉接受 社会主义核心价值教育创造条件。高校应积极开展丰富多 彩、积极向上的各类主题研究生教育活动, 搭建研究生学 术刊物、研究生网络服务等交流平台, 将社会主义核心价 值体系的基本要求和基本内容有效融入到校园文化建设 中, 以培育优良的校风、教风和学风为核心, 建设兼具时 代特征和学校特色的校园文化, 为研究生德育教育营造良 好的校园氛围。 
4.6 加强辅导员队伍建设, 不断提高研究生德育教育的专 业化水平

辅导员是研究生德育工作的直接参与者, 建设一支政 治觉悟高、思想品德好、业务水平硬的高水平专职辅导员 队伍, 是研究生德育教育的重要保证。优秀的研究生辅导 员应不断加强自身对马克思主义哲学、教育学、政治经济 学、心理学、法学、社会学等多学科理论知识的学习, 以 不断提高自身的综合素养和工作能力; 而且能够主动地将 理论运用于实践工作, 从多渠道入手, 拓宽教育途径, 创 新教育方式, 增强研究生德育教育的针对性和实效性。优 秀的研究生辅导员要善于倾听和平等交流, 做到思想上引 导学生、生活上关心学生、情感上感动学生。

4.7 强化导师德育意识, 充分调动导师参与研究生德育教 育的积极性

研究生导师的育人作用不仅体现在传授业务知识方 面, 也体现在思想政治素质和道德风范影响方面。导师的 为人师表和言传身教能够引导学生树立正确的理想信念、 把握正确的政治方向、养成优良的学风作风和培养良好的 社会责任感。通过将研究生德育教育要求贯穿于导师的遴
选、考核、任用等环节, 充分考察导师的思想政治素质和 职业道德水平, 加强导师队伍建设, 强化导师的德育意识, 充分调动研究生导师参与研究生德育教育的主动性和积极 性。

\section{参考文献(References)}

[1] "The Ministry of Education Several Opinions on Strengthening and Improving the graduate students' Moral work", April 6, 2000

[2] "The Ministry of Education Several Opinions on Further Strengthening and Improving the graduate students' Ideological and Political", November 17,2010

[3] Wenli Yu and Ye zhou, "Research on whole process education of the universities' social core value system," in Guangming Daily Press, May 2010.

[4] Ping Liao, "Discussion on the basic path of the universities' social core value", Leading Journal of Ideological \& Theoretical Education, August 2011, pp.98-101

[5] Songming Xie, "Discussion on the connotation and components of the social core value", Journal of Huaibei Coal Industry Teachers' College, June 2007, pp.57-60. 